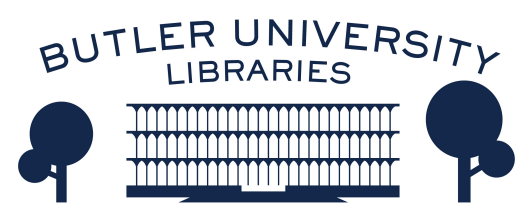

Journal of Hindu-Christian Studies

Volume 21

Article 7

January 2008

\title{
Nine More- or Less-related Observations on Historical Approaches to Hindu-Christian Studies
}

Brian K. Pennington

Follow this and additional works at: https://digitalcommons.butler.edu/jhcs

Part of the Religion Commons

\section{Recommended Citation}

Pennington, Brian K. (2008) "Nine More- or Less-related Observations on Historical Approaches to HinduChristian Studies," Journal of Hindu-Christian Studies: Vol. 21, Article 7.

Available at: https://doi.org/10.7825/2164-6279.1406

The Journal of Hindu-Christian Studies is a publication of the Society for Hindu-Christian Studies. The digital version is made available by Digital Commons @ Butler University. For questions about the Journal or the Society, please contact cbauman@butler.edu. For more information about Digital Commons @ Butler University, please contact digitalscholarship@butler.edu. 


\title{
Nine More- or Less-related Observations on Historical Approaches to Hindu-Christian Studies
}

\author{
Brian K. Pennington \\ Maryville College
}

FOR the purposes of this panel discussion, it seems more appropriate to make a series of suggestions and observations about the difficulties and promises of writing history within a Hindu-Christian framework than to offer a paper arguing a single point or perspective. Hindu-Christian history presents a particular set of challenges given the shifting political and material conditions that have attended the dramatic encounter between these disparate cultures and traditions. In what follows I attempt to articulate some of the larger issues with which I wrestle as I study and write HinduChristian history.

1. The scope for Hindu-Christian historical inquiry is broad. This general comment about the current state and future promise of a Hindu-Christian history announces the obvious but still seems a necessary starting point. A survey of Hindu-Christian histories published in the last few decades reveals a sweeping range of potential inquiry. The history of direct interactions between Christians and Hindus has been of central concern, whether those interactions have been conducted in dialogic mode (Brockington 167-89; Kopf; Coward) or in contest (Copley). Studies of missionary undertakings and Indian responses to them have occupied a very significant amount of historians' attention, both because of the dramatic nature of that encounter but also because of the substantial archival record it has left behind. While this archival record is in no danger of being exhausted soon, there are, nevertheless, other areas in which the potential for further historical research on the overlap of these two religious traditions is great. Many good ethnographies which highlight Hindus in Christian cultural settings and vice versa contain ample historical material (e.g. Dempsey 2000 and 2004). Enigmatic or syncretistic figures or movements that display deep investment in Hindu and Christian worlds provide highly illustrative scenarios inviting us to consider the unfolding history of Hindu-Christian interaction. Julius Lipner's work on Brahmanbandab Upadhyaya, Brian Hatcher's on Vidyasagar, and Saurabh Dube's on the Satnamis of Chattisgarh, for example, examine how Hindu and Christian traditions have coalesced in persons and communities. A focus on living contact between Christians and Hindus or the convergence of Hindu and Christian influences in the past is only one species of historical engagement, however, as the proliferation of studies devoted to the representation of Hindus by Christians (e.g. Figueira) and Christians by Hindus (e.g. Fox-Young) has shown. And while our understanding of the colonial period in general has been enhanced thanks to histories informed by Hindu-Christian studies, it is critical to note that it is not only the history of the subcontinent itself to which Hindu-Christian studies allows us special access, but also that of Europe and North America, in which colonial ambitions or resistance to them have often been

Brian Pennington is Associate Professor of Religion at Maryville College, Maryville, TN. He is author of Was Hinduism Invented?: Britons, Indians, and the Colonial Construction of Religion (Oxford University Press, 2005). He specializes in colonial-era Hindu-Christian interaction and has written also on method and theory in the study of religion. His current research project is a comparative analysis of transitions now underway in the regional religious traditions of the Himalayan and Appalachian mountains. 
colored by religious ideologies, discourses, or practices that show the imprint of HinduChristian encounter (van der Veer; Pennington 23-100).

2. The archive is primary, but the archive speaks with a forked tongue. Its elisions, glosses, and absences often mean we have to write history in spite of the archive, not because of it. The inequities and injustices of colonialism can be compounded by the production of history that does not seek to redress the imbalances in the surviving record (cf. Patil). The grave disparity in historical materials testifying to the nature of past Hindu-Christian encounter, however, is also attributable to a variety of reasons not having to do directly with power differential, such as the insularity of Hindu pandits in the colonial period and the scrutiny of self and other that characterized evangelical missionaries' spiritual discipline (Fox-Young 14; Pennington 79-80). By virtue of cultural proclivities and proselytizing theologies, Christians initiated encounter and recorded it more than Hindus. The vast mjority of archival materials that testify to the character of relations and exchanges between Hindus and Christians in both the near and distant past records the perspectives of Christians. Not only does the weight of material heavily favor Christian perspectives, but missionaries, by virtue of their commitment to journal-writing, recordkeeping, and publication, have also shifted our perspective about this contact over the last 500 years. Much of what we think we know about Hindu-Christian encounter derives from the observations of only a narrow segment of the Christian population: overseas missionaries and their converts (see Copley, e.g.).

Historians have experimented with means of redressing this imbalance by applying insights from ethnography (John and Jean Comaroff), by giving careful and sustained attention to the few major Hindu figures who wrote a significant amount on or to Christians (Das; Sharma), by combing through the records of princely states not directly ruled by the British (Kawashima), by extrapolating from comparative history (Viswanathan), by "counter-reading" missionary or Orientalist sources to produce their own critique (Županov; Trautmann), and by foregrounding Indian agency in the history of Hindu-Christian encounter (Frykenberg and Low). The Subaltern Studies Collective has, at times, nodded in the direction of articulating a more balanced Hindu-Christian history and produced a handful of pieces that regard religion, particularly in its instrumental capacity, as a source of insurgency or protest (see Novetzke).

3. New perspectives and methods for analyzing the work and lives of Christian missionaries are long overdue. Missionaries occupy a particularly odd historical location because they have served as both our primary archivists of HinduChristian contact and its primary architects and agents. For all the work now published on missionaries and missionary bodies, the history of religions has not yet successfully (in my view) rendered their lives and motivations in terms of the same complex religious and cultural weaves as it has Hindus. If ethnography, anthropology, and history of religions are the means by which western discourses have indelibly engraved culture and religion into the subjectivities of Hindu historical actors, they have yet to exoticize the missionary and thereby render him in parallel terms. ${ }^{1}$

4. The assumption that there is an accessible past that documentary evidence preserves and the principle that assiduous, archival sleuthing will reveal it are misguided. Simplistically put the past is gone. As Fasolt observes, its absence underscores our fundamental conviction that it is immutable and therefore retrievable, in fragmentary but transparent form, through artifacts that survive into the present (5). The paradigmatic historical endeavor is thus taken to be first, a quest for these fragments (i.e. sources, data), and second, their reassembly into a narrative structure that purports to approximate the original frame 
of events, much as a paleontologist reassembles a partial skeleton and fills in the missing bits. The fragments of the past that we possess, however, do not constitute the past itself but are its signifiers (Fasolt 12). Those signs point us to the past and suggest its outlines. Our histories cannot contradict the messages of documentary evidence. Nevertheless, to treat the archive as if it is coextensive with the past is to commit ourselves to a kind of fundamentalism that conflates signified and signifier. In the field of Hindu-Christian studies, given the imbalance in the archive, the greatest danger this paradigm poses may be the subtle reinscription of Christian hegemony and Christian concepts. A critical function of the Hindu-Christian archive, therefore, is to establish a kind of limiting condition. It should not exhaust what we can know or say, nor must it circumscribe our narrative. It does, however, through the concatenation of the limits it establishes, create the space within which we engage the past.

5. The articulation of historical meaning is less a process of discovery than an engagement with a partially imagined past for the purposes and in the interests of some contemporary party. Multiple meanings lie in wait in any set of historical artifacts. History is itself a cultural product; writing history is itself a historical process. They are both implicated in multiple sets of social and material arrangements. To function as a historian without this explicit awareness is to fall prey to the notion that the historian's task is to recover and represent the "facts" of the past and thereby reconstruct it (Munslow 2006b: 3). Writing Hindu-Christian history is to narrativize documentary evidence that is, in fact, already narrativized. The archival evidence that is available to us has survived to the present because some institution or individual regarded it as a record of a trajectory of ideas or events. It already exists, indeed has always existed, in preexistent fields of relations, as the pieces of multiple narratives. The degree of prior narrativization of any documentary evidence is greater when items have been deliberately archived, for, in that case, they were preserved as a potential future index of a particular set of historical narratives. Our archives do not present us with neutral, unadorned facts that we stitch into a narrative that establishes the "truth" of the past. As a representation of the past, historical narrative "stands for something by taking its place" (Straub 47). Our narratives, therefore, function "as both a surrogate for the past and as a medium of exchange in our active engagement with it" (Munslow 2006b: 6). That engagement always serves the interest of the present; Hindu-Christian history serves a Hindu-Christian present.

A standard mode of writing HinduChristian history aims to make archival material available in the narrative and in the notes and to treat the archive as if it were transparent and unproblematic. More inventive (which is not to say fanciful) histories of colonial encounter seek the multiple possibilities in the archive and regard their task more as the renarrativization of data than as the recovery and presentation of a preexistent narrative. ${ }^{2}$

6. Projected on the past, "Hindu" and "Christian" threaten to warp the data. Like "religion" itself, its component beliefs, practices, and dispositions, and the concept of religion in general, "Hinduism," "Christianity," and their adjectival forms are historically contingent entities, their meaning to self and other constantly shifting over time and with respect to the specific contexts in which they are used. In the work of historians of religion, they are indispensable indices of community and identity, but ever problematic.

7. Regrettably, the methods of oral history have yet to penetrate Hindu-Christian studies, in spite of fact that the period of the most extensive and variable HinduChristian contact has been the relatively recent past. Oral history relies on personal memory rather than documentary evidence, and for that reason, it is often maligned. Memory is fickle, and personal narrative of 
the near or distant past is subject to the quiet reconfiguring of experience according to self- or community interest. Following from the principle articulated above, namely, that documentary evidence itself, to greater or lesser degrees, is also already narrativized, it follows that oral narratives participate in the same dynamic and are available to the historian in a similar condition. Every gazetteer, vernacular newspaper item, journal, statistical report, or others of those sources that commonly fill our archives is similarly situated in a field of relations and already oriented toward a particular telling of a tale out of many possibilities. Alun Munslow has defended oral history in these terms: "The mere existence of a source does not endow it with 'objectivity' or 'truth,' whether it is documentary or oral. All history has a purpose, it is constructed for someone and, arguably, it is in the nature of oral history to forcefully remind us of that central feature of the historical undertaking" (Munslow 2006a: 198). A movement to record surviving testimony, particularly of Indian agents, to past Hindu-Christian encounter would constitute an extremely important intervention in the evidentiary record that is characterized by such disparity between Hindu and Christian voices.

\section{Experimental modes of writing history} that develop alternative models of narration to the plotlines and narrative voices of received historiography hold great promise for enhancing our engagement with the past. Hayden White long ago pointed out that the genre of history follows the conventions of the nineteenth-century novel: it is dominated by the third-person narrative, that narrative relates sequential, temporal events, and it displays a clear beginning, middle, and end (White 1973). The dominance of this mode of historical narration has rendered a set of standard plot lines that are now fairly worn. These plots typically feature cohesive communities coming into contact and subsequently responding or adapting to one another in positive or negative ways. HinduChristian history, however, remains deeply implicated in and relevant to contemporary realities-from the local to the geopolitical-that defy those plotlines and characters. Alternatively rendered accounts of a Hindu-Christian past, if informed by and faithful to the documentary evidence, may open up new social and political space for reimagined Hindu-Christian relations by illuminating the contestations and the transformations that have marked that past .

I wish to be clear: I am neither inviting nor calling for the invention of history to suit contemporary politics. The cavalier and irresponsible handling of historical and ethnographic evidence by both Hindus and Christians in the past and present for overt self-interest or gain must be a target for scholars who oppose communalism or chauvinism. From Harrapa to Ayodhya we have seen the veneer of historicism applied to aggressive and intolerant political programs. Edwin Bryant's lament that the "unscholarly, offensive, and dogmatic" branding of Indian histories and scholars as uncritical and unreflective cheerleaders for Hindutva (2001: 277) could equally be applied to those charges of covert evangelicalism or neo-colonial hegemony that have been lodged against good-faith historical investigations of Christians in India. Too much Hindu-Christian history has been crafted, as Gyanedndra Pandey puts it, as an epic tale of an ongoing contest between Rama and Ravana (1995: 386). The dominance of a single mode of narrating history coupled with the preponderance of plot-lines that feature Christian/western hegemony and Hindu response/resistance should start to call these modes of narration into question. ${ }^{3}$.

All previous observations point to this final one:

9. The ultimate value of a Hindu-Christian history is a Hindu-Christian future. Writing history is the production of knowledge. The knowledge produced by history, however, is not of a static and knowable reality, but one that suggests the character of the world and the duties that accrue to us as a result. The Hindu-Christian 
past may be a difficult past to come to terms with, but in its difficulties lies a call to remain mindful of the moral components of historical narrative. Those of us who create the past for the present cannot ignore the role our work might play in the shaping of a Hindu-Christian future. On the moral elements of historical writing, Jürgen. Straub has written, "The present does not only create narrative representations of the past in order to help explain the present from the narrator's perspective; narrative representations also lead into a future by suggesting certain actions to subjects....[W]e could say that they impose responsibilities on subjects. On the other hand," he continues, "where historical memory is deficient or entirely absent,

\section{Notes}

1 The work of John and Jean Comaroff and those whom they have inspired such as Dube and Kent have made some progress in this direction. In the area of Buddhist-Christian encounter, Eric Reinders provides a good model.

${ }^{2}$ While I greatly admire his work, to my mind Geoffrey A. Oddie exemplifies the first method; see, e.g., his fairly optimistic evaluation of the possibilities that lie in the archive, (4-7). Eliza Kent's recent work, on the other hand, reads the gaps in the archive to appreciate "the inherently ambiguous and multivalent nature" of the testimony it preserves and recognizes that the direct and indirect evidence in the archive can render "vastly different meanings in different contexts" (242).

${ }^{3}$ A recently edited collection of experimental historical narration by established historians aims to demonstrate the insights about the past as well as the social and political spaces potentially made possible by such narrative innovations as present tense, selfreflexivity, and first- or second-person narration (Munslow and Rosenstone). An excellent example of the kind of careful historical work on encounter rendered in alternative narrative form is Greg Dening's "Writing, Rewriting the Beach" in that volume.

\section{References}

Brockington, John. Hinduism and Christianity. New York: St. Martin's Press, 1992.

Copley, Anthony. Religions in Conflict: Ideology, Cultural Contact and Conversion in Late Colonial India. New Delhi: Oxford University responsible action becomes a vain hope" (65). While Straub echoes my own concerns about the abuse of history, reminding us that history and the social need for history can be manipulated to provide justification or defense of self, absolve one's conscience, or manufacture idealized persons and communities, he also believes that historical narratives "invite others to share a conception of reality" (68). If the reality to which we invite our readers is responsible, compelling, and free from selfaggrandizement, then it can provide "a basis for consensual judgments and coordinated, cooperative action" (66). It can, that is, create a shared past, a mutual present, and a hopeful future.

Press, 1997.

Coward, Harold, ed. Hindu-Christian Dialogue: Perspectives and Encounters. Maryknoll, NY: Orbis, 1989.

Das, Sisir Kumar. The Shadow of the Cross. New Delhi: Munshiram Manoharlal, 1973.

Dempsey, Corinne G. Kerala Christian Sainthood: Collusions of Culture and Worldview in South India. New York: Oxford University Press, 2000.

----. The Goddess Lives in Upstate New York: Breaking Convention and Making Home at a North American Hindu Temple. New York: Oxford University Press, 2005.

Dening, Greg. "Writing, Rewriting the Beach." In Experiments in Rethinking History. Edited by Alun Munslow and Robert A. Rosenstone, 3055. New York, Routledge, 2004.

Dube, Saurabh. Untouchable Pasts: Religion, Identity, and Power among a Central Indian Community, 1780-1950. Albany, NY: SUNY Press, 1998.

Fasolt, Constantin. The Limits of History. Chicago: University of Chicago Press, 2004.

Figueira, Dorothy Matilda. Translating the Orient: The Reception of Sakuntala in NineteenthCentury Europe. Albany, NY: SUNY Press, 1991.

Frykenberg, Robert Eric and Alaine Low. Christians and Missionaries in India: Cross-Cultural Communication Since 1500; With Special Reference to 'Caste, Conversion, and Colonialism. Studies in the History of Christian Missions. Grand Rapids, MI: Eerdmans, 2003.

Hatcher, Brian A. Idioms of Improvement: . Calcutta: Oxford University Press, 1996. 
Kawashima, Koji. Missionaries and a Hindu State: Travancore 1858-1936. Delhi: Oxford University Press, 1998.

Kent, Eliza F. Converting Women: Gender and Protestant Christianity in Colonial South India. New York: Oxford University Press, 2004.

Munslow, Alun and Robert A. Rosenstone, eds. Experiments in Rethinking History. New York, Routledge, 2004.

Muslow, Alun. The Routledge Companion to Historical Studies. 2d Ed. London: Routledge, 2006.

----. Deconstructing History: 2d Edition. London: Routledge, 2006.

Novetzke, Christian Lee. "The Subaltern Numen: Making History in the Name of God." History of Religions 46 (2006): 99-126.

Oddie, Geoffrey A. Hindu and Christian in SouthEast India: Aspects of Religious Continuity and Change, 1800-1900. London Studies on South Asia 6. London: Curzon Press, 1991.

Pandey, Gyandendra. "The Appeal of Hindu History." In Representing Hinduism: The Construction of Religious Traditions and National Identity. Edited by Vasudha Dalmia and Heinrich von Stietencron, 368-88. New Delhi: Sage Publications, 1995.

Patil, Parimal. "A Hindu Theologian's Response: A Prolegomenon to "Christian God, Hindu God." In Hindu God, Christian God: How Reason Helps Break Down the Boundaries between Religions, ed. Francis X. Clooney. New York: Oxford University Press, 2001, 185-95.

Pennington, Brian $\mathrm{K}$. Was Hinduism Invented? Britons, Indians, and the Colonial Construction of Religion. New York: Oxford University Press, 2005.

Reinders, Eric Robert. Borrowed Gods and Foreign Bodies: Christian Missionaries Imagine Chinese Religion. Berkeley: University of California Press, 2004.

Sharma, Arvind, ed. Neo-Hindu Views of Christianity. Leiden, E. J. Brill, 1988.

Straub, Jürgen. "Telling Stories, Making History: Toward a Narrative Psychology of the Historical Construction of Meaning." In Narration, Identity, and Historical Consciousness, ed. Jürgen Straub, 44-98. New York: Berghan Books, 2005.

Trautmann, Thomas R. Aryans and British India. Berkeley: University of California Press, 1997.

Veer, van der Peter. Imperial Encounters: Religion and Modernity in India and Britain. Princeton, NJ: Princeton University Press, 2001.

Visvanathan, Gauri. Outside the Fold: Conversion,
Modernity, and Belief. Princeton, NJ:

Princeton University Press, 1998. White, Hayden. Metahistory: The Historical Imagination in Nineteenth-Century Europe. Baltimore: Johns Hopkins University Press, 1973.

Županov, Ines G. Disputed Mission: Jesuit Experiments and Brahminical Knowledge in Seveneenth-Century India. New Delhi: Oxford University Press, 1999. 